\title{
Moodle-based E-Learning Model for Critical Thinking in the Lesson of Electromagnetic Induction
}

\author{
Ketang Wiyono $^{1, \text { a })}$, Zulherman ${ }^{1}$, Saparini ${ }^{1}$, Melly Ariska ${ }^{1}$, Rini Khoirunnisa ${ }^{1}$, \\ Sri Zakiyah ${ }^{2, b)}$ \\ ${ }^{1}$ Physics Education Department, Faculty of Education and Teacher Training, Universitas Sriwijaya, \\ Indralaya, South Sumatra, 30663, Indonesia \\ ${ }^{2}$ Surulangun State High School, Musi Rawas Utara, South Sumatra, 31656, Indonesia \\ $\bowtie:{ }^{a}$ ketangw.fkipunsri@gmail.com
}

\begin{abstract}
This study aims to develop a valid and practical e-learning model for critical thinking skills using the moodle platform in the lesson of electromagnetic induction. Dick and Carey instructional design model is applied for the product development — which consists of nine stages, (1) instructional goals identification, (2) instructional analysis, (3) learners and contexts analysis, (4) objective performance arrangement, (5) assessment instruments development, (6) instructional strategy's plan, (7) instructional material selection, (8) preparation for conducting a formative evaluation of the instruction, and (9) revise instruction. The results reveal the moodle design is valid and practical regarding expert and user perspectives, respectively. Besides, there is an improvement of student's critical thinking skills according to the obtained n-gain score, which stands for 0.38 .
\end{abstract}

Keywords: e-learning, moodle, instructional design, critical thinking

\section{INTRODUCTION}

In this day and age, the development of craftsmanship and technology in higher education has shifted the learning paradigm from conventional to technology-based (Newman 2012). Both termsscience and technology, are simultaneously interconnected in producing numerous learning product innovations such as e-learning (Archambault 2010; Huang 2010; Cronje 2010).

E-learning is an integrated learning system that associates the 4C skills - critical thinking, creative thinking, communicating, and collaborating, into the computer environment. It is widely considered proper preparation for facing 21st-century challenges (Chandra 2018). Furthermore, e-learning involves utilizing a multi representative construction model and allows students to experience a dynamic, interactive, and multiple access to a wide range of information (Benta 2014). This, therefore, the blended product of the learning process with online would provide the shot in the arm for both teachers and learners, as two main factors in-class activity. Besides, online learning ideas are generally constructivism-based models such as inquiry-based, problem-based learning, independent, and active learning, which might contribute to learners' self-enhancement as constructors of their own knowledge — well-known as SRL (Self Regulated Learning) (Liaw 2013). Moreover, the self-regulated learners are personally motivated, their own master, and metacognitively oriented (Gaeta 2012). In particular, this metacognitive turns out to be a contributing factor in fostering critical thinking skills (Sadeghi 2014; Peña-ayala 2015). 
According to Haghparast (2014), these two approaches might encourage CT skill; general settings and infusion approach. These ways show an excellent line, whereas the public environment separates CT skills from coursing materials while the infusion approach embeds them. Additionally, Rieckmann (2012) outlines that cultivating critical thinking is crucial for college graduates, as they are about to grow up in a modern society that requires competent human resources. Thus, many developed online learning that provides realistic visualization for any number of different lessons nowadays. A recent study describes the development of e-learning using WordPress for physics materials in a straightforward process. This research promotes student enhancement in 21st-century skills through the 5E learning cycle strategy (Bakri 2018). Another related paper (Muliyati 2019) also develops online for heat and thermodynamics topics by utilizing secondary school ICT properties. Kotzer (2012), for another instance, design an e-learning environment using the Moodle platform in the lesson of science, mathematics, and technology. In conclusion, the learning materials are possibly arranged in such an elearning form as its importance to foster learners' skills according to the 21st-century framework.

Moodle is an example of an open-source learning management system that allows users to develop e-learning. This online system provides benefits such as user-friendly, manageable, easily accessible by digital devices, and enables the integration of various learning sources (Hirschel 2012). Moreover, moodle is endowed with a pedagogical aspect as it was generated under the teaching approach, which stresses the multimedia construction through experiencing multi-sensory and provided active learning (Elias 2010). Its blueprint is based on socio-constructivist media, which proposes an inquiry and discovery-based learning tools (Psycharis 2013). To sum up, these intrinsic components of the moodle platform promote student enhancement regarding their 21st-century skills.

Regarding the prominent role of the internet nowadays, moodle might stand as an online tool that provides advantages in developing students' CT. This paper presents our developed moodle-based course, which includes an array of activities that combine critical thinking skills with content in physics subject. Specifically, in the syllabus of electromagnetic induction, because electromagnetic induction is an essential material in physics but based on an analysis survey of the needs of electromagnetic induction material, students are considered difficult materials because of its abstract material. Besides, the limited hours of classroom lessons make students sometimes lack enough time to study them. Therefore, it takes a means that can facilitate learning it. Based on survey needs in learning, electromagnetic induction students need other media such as images or videos to make it easier for them to understand. E-learning is one of the learning models that can facilitate both media and learning time

The rest of this paper is organized as follows: Section 2 outlines the research methods. Secondly, section 3 provides the results of each conducted stage. And finally, in section 4, the conclusion and further implications are described.

\section{METHODS}

This study aims to produce online learning using the moodle platform, specifically in the lesson of electromagnetic induction. To build this media, we conducted development research, according to Dick and Carey's model, which is embedded into ten components (Dick and Carey 2015). Furthermore, it is summarized into five development procedures that interpret the ten components: analysis, development, design, implementation, and evaluation. Due to the research goal, the process is restricted into nine necessary steps, which are illustrated in FIGURE 1 (Dick and Carey 2015). This method is essentially the same as (Bakri 2018) and (Muliyati 2019). 


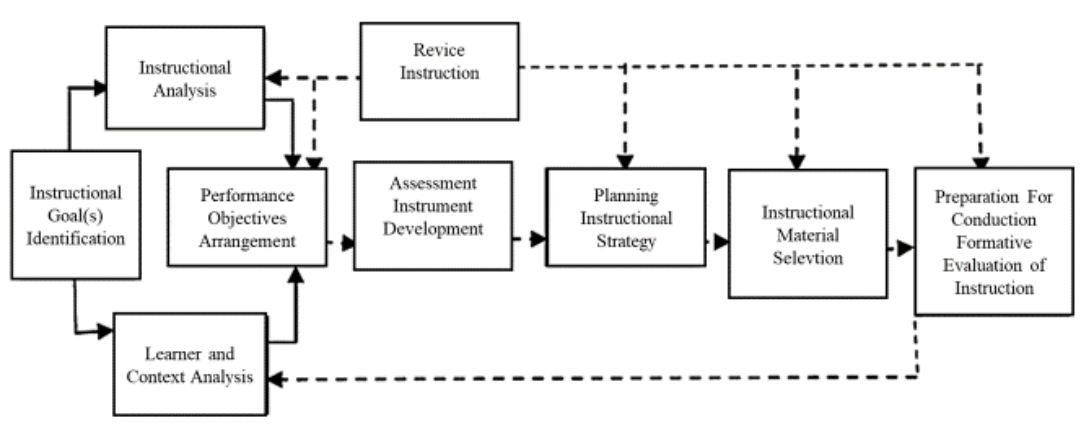

FIGURE 1. Dick \& Carey Instructional Design Model

Furthermore, during the formative evaluation stage, we used reliable techniques based on (Dick 2015) for sample selection, the students of Physics Education major at Universitas Sriwijaya. Also, expert reviewers were engaged in product validity. And finally, for the field trial, the apparatus is composed of pretest and posttest to obtain $\mathrm{N}$-gain.

\section{RESULTS AND DISCUSSION}

In the initial stage of this research, determining learning aims is before the development procedure. The completed instructional goals can subsequently be used to conduct instructional analysis before analyzing the product's learners and contexts. Moreover, this analysis stands as a matrix for objective performance arrangements following critical thinking skill indicators. Further construction results in other related learning tools such as lesson plan, instructional strategy, set of instructional materials, and assessment as an interlocking connection to desired learning outcomes based on (Malik 2019). Table 1 outlines the contents that align with the CT skills of the e-learning.

TABLE 1. Critical thinking skills element of the developed E-learning

\begin{tabular}{|c|c|}
\hline Chapter & CT's indicator \\
\hline The fundamental of static magnetic field experiment & Determining and conducting observation \\
\hline Magnetic induction & $\begin{array}{l}\text { Focusing on identification, problem-solving, } \\
\text { and problem analyzing }\end{array}$ \\
\hline The dynamic of charged particle in magnetic field & $\begin{array}{l}\text { Performing deduction and induction, actively } \\
\text { questioning and answering the questions }\end{array}$ \\
\hline $\begin{array}{l}\text { The equation of stationary magnetic field and the magnetic } \\
\text { vector potential }\end{array}$ & $\begin{array}{l}\text { Performing deduction and induction, actively } \\
\text { questioning and answering the questions }\end{array}$ \\
\hline Faraday’s law & Determining and conducting observation \\
\hline
\end{tabular}

\section{Product Design}

After completing the topic development phase, designing e-learning can be performed. This research utilizes the Moodle platform as an online media creation. The blueprint, furthermore, is prior conducted as a guide for generating the e-learning. FIGURE 2 illustrates the flowchart of the e-learning creation.

Electromagnetic Induction e-learning was inaugurated as a correspondence learning environment that connects learners and lecturers through assignment and discussion portal. The primary material is Electromagnetic Induction, which is divided into two parts with several supporting chapters in each topic. Also, participants might track their progress with the provided calendar that refers to the timetable.

Moreover, the program of this online offers learners a dynamic visualization of topics related to video and simulation. Furthermore, the course arrangement enables students to work and interactively engaged because its offer's instructional way is the same as the scientist performed. It is clearly seen through TABLE 1 that the materials are arranged from essential to advance level, which challenges the student and encourages them to think critically and creatively. Furthermore, as previously described, 
the moodle platform integrates a wide range of information and learning sources. Therefore, the product intervented with a set of problem-based solving materials and questions and multimedia resources such as video, pictures, and simulation. FIGURE 3 and FIGURE 4 signify these implementations.

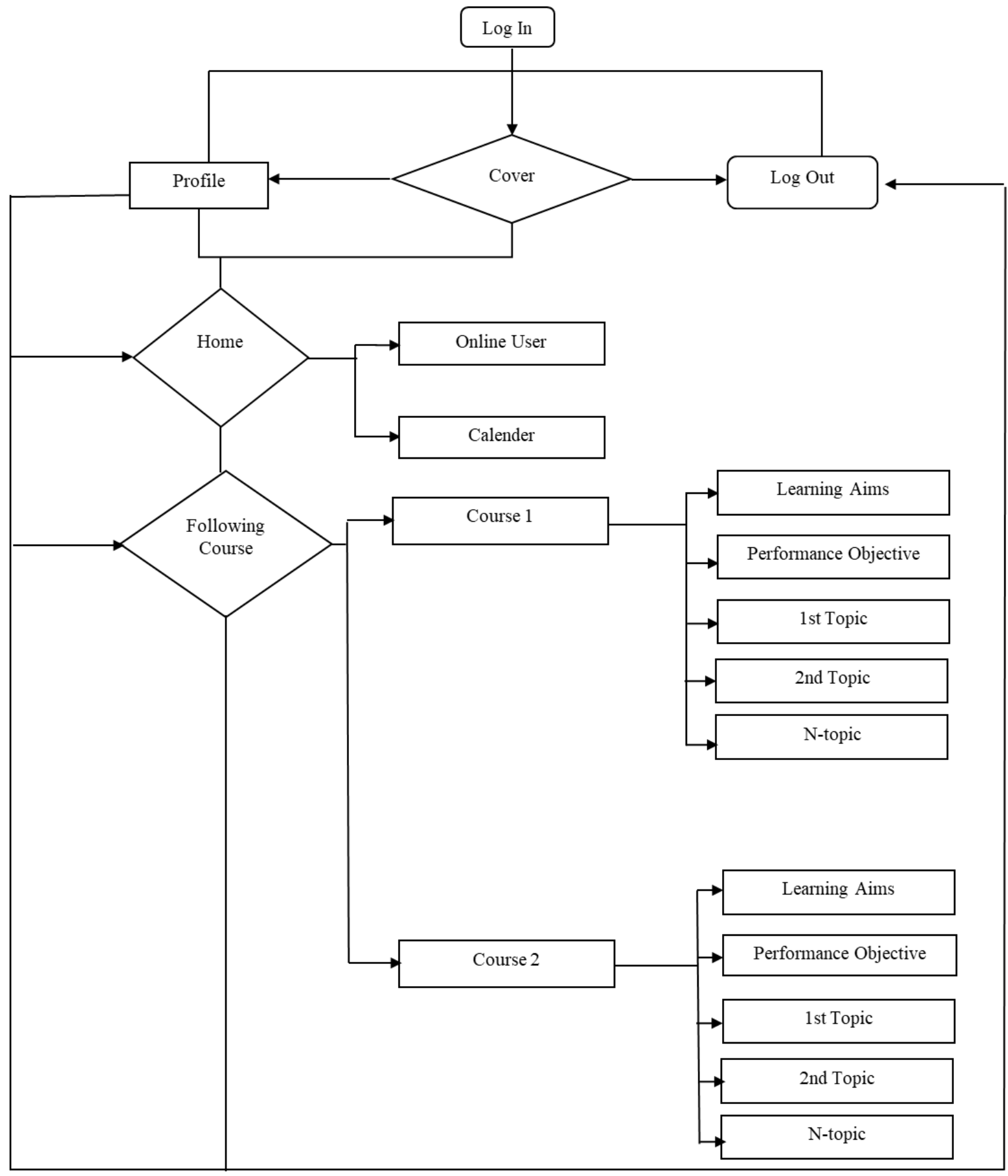

FIGURE 2. Flowchart of e-learning algorithm. 


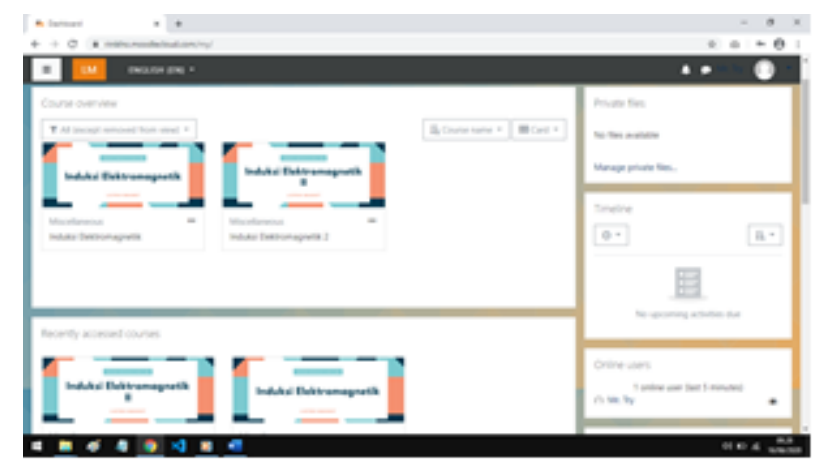

(a)

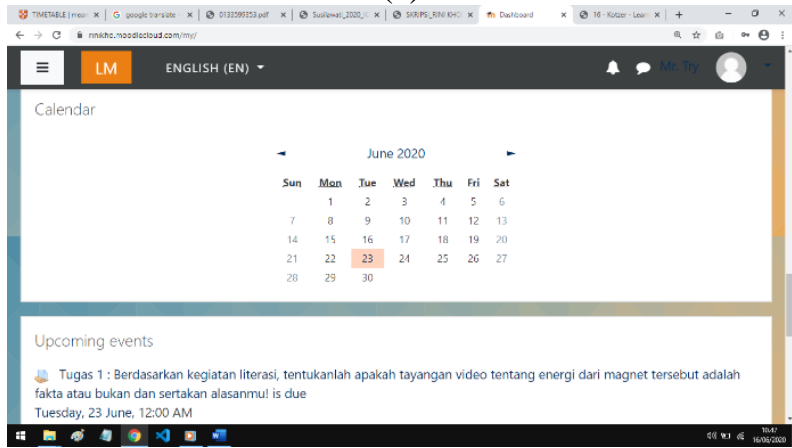

(c)

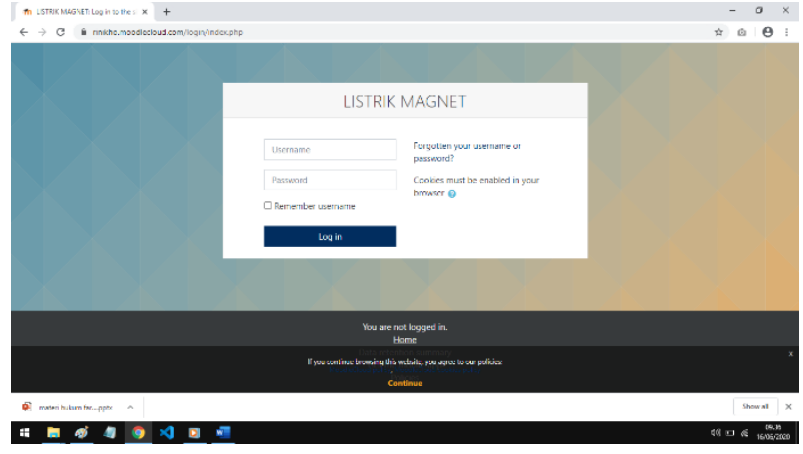

(b)

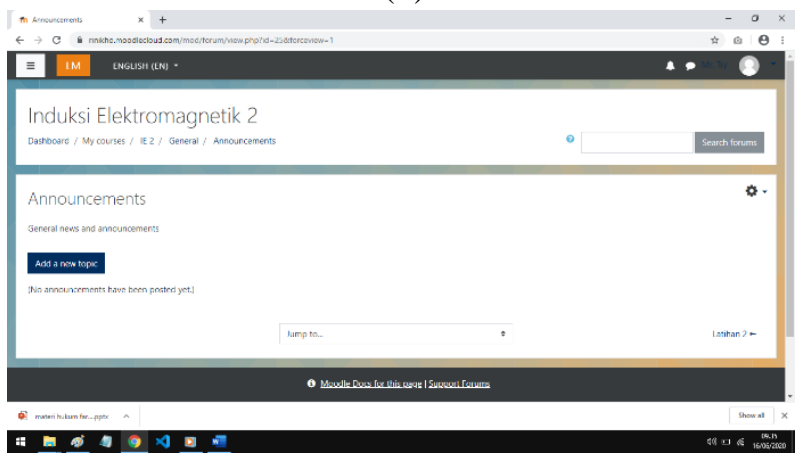

(d)

FIGURE 3. Picture (a) and (b) presents the login template and home, respectively. Image (c) and (d) separately shows the timetable along with the upcoming events and annoucement page

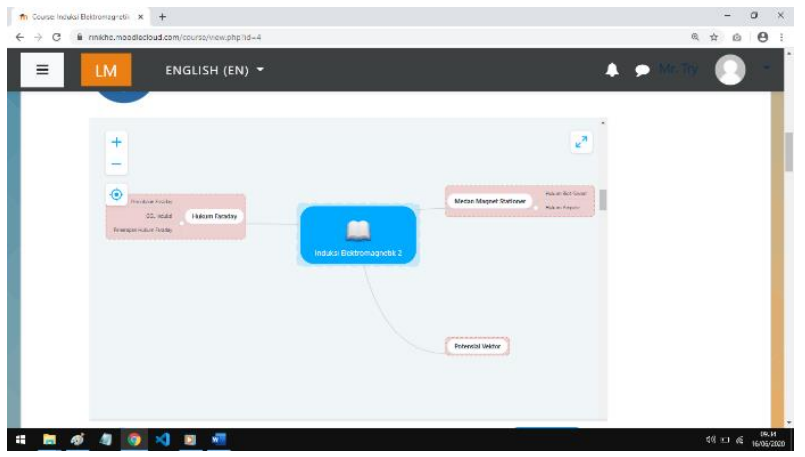

(a)

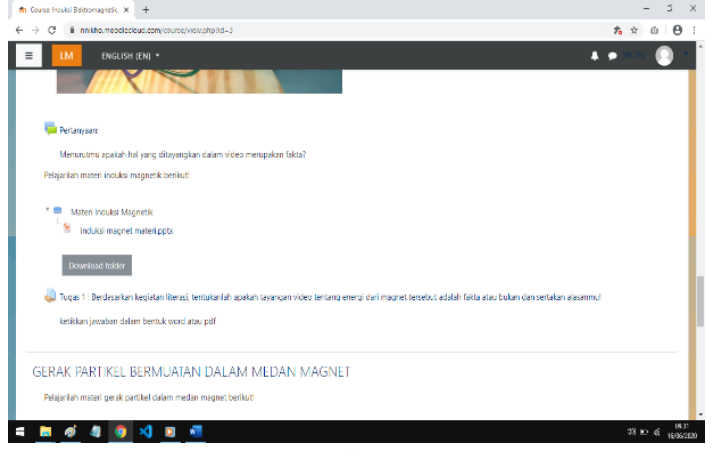

(b)

FIGURE 3. Picture (a) presents the mind mapping of the general lesson in specific chapter with zoom in/out button. Image (b) visualizes the downloadable course books and task assignment for students 


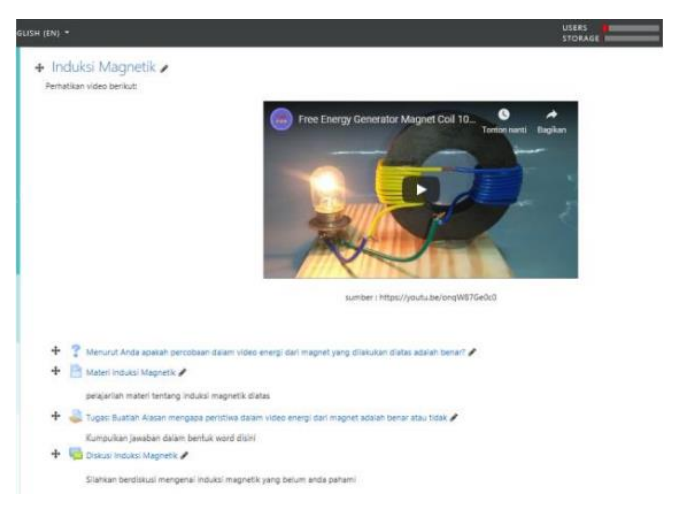

(c)

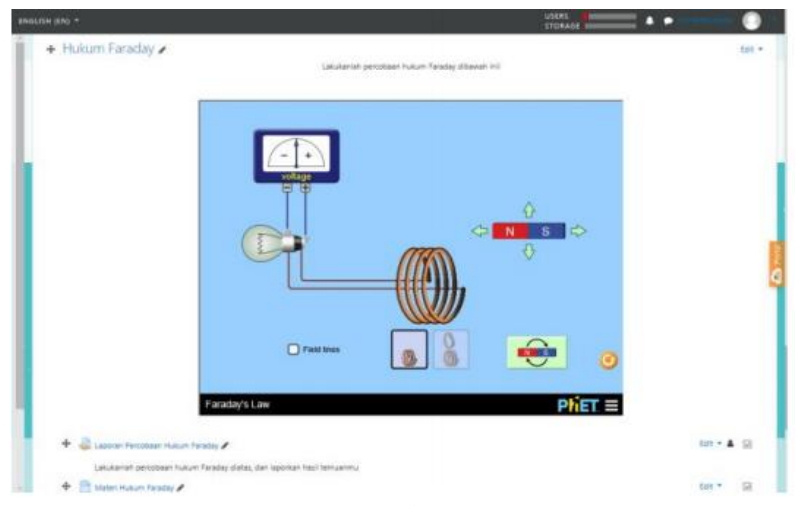

(d)

FIGURE 4. (a) learning video sources regarding experiment of generator magnet coil, and (d) student's practicing Faraday Law through simulation.

\section{Formative Evaluation Results}

For the formative evaluation, expert judgment, one-to-one evaluation; and small group evaluation are required for revision purposes (Dick 2015). These stages utilize questionnaires on a Likert scale, according to (Sugiyono 2015). The procedure is in line what used by (Bakri 2018), (Muliyati 2019), and Susilawati (2020), with some modifications. For the expert review, we involve two and a lecturer from the Physics Education Major of Sriwijaya University and Faculty of Computer Science, respectively.

The results of design feasibility, according to experts, are revealed in TABLE 2. Regarding the outlined data, it is clearly seen that the moodle e-learning is valid as an instructional media.

TABLE 2. Validity Score by Experts

\begin{tabular}{lcc}
\hline \multicolumn{1}{c}{ Aspect } & Score & Category \\
\hline Material content & $90.00 \%$ & Very valid \\
Instructional Design & $100 \%$ & Very valid \\
E-learning feasibility & $81.81 \%$ & Valid \\
\hline
\end{tabular}

Separately, the one-to-one evaluation stage is conducted to evaluate the instructional based on the learner's perspective. This phase includes three main evaluation; clarity, impact, and feasibility (Dick 2015).

Regarding one-to-one evaluation, the students provide positive feedback according to the initial prototype with minor revision. They state on their questionnaires that learning electromagnetic induction becomes more flexible and interactive by using this developed online learning. Moreover, the provided question is challenging in enhancing the way they think. All of this information is further considered as revision purpose-prototype 2 .

Secondly, the small group evaluation aims to determine the effectiveness of prototype two and determining the e-learning capability for automated learning. TABLE 3 presents the outcome of these two evaluation stages following students as the user.

TABLE 3. One-to-One and Small-Group Evaluation Results

\begin{tabular}{lcc}
\hline \multirow{2}{*}{ Aspect } & \multicolumn{2}{c}{ Score } \\
\cline { 2 - 3 } & One-to-One & Small Group \\
\hline Content clarity & $90 \%$ & $88.15 \%$ \\
Impact on learners & $91.11 \&$ & $90 \% \%$ \\
E-learning feasibility & $79.44 \%$ & $85.93 \%$ \\
\hline
\end{tabular}

In the final stage, the field trial aims to evaluate whether the revision after small-group works effectively and whether it is possible to implement it in such an intended learning setting. For conducting this test, 30 students of Physics Education Major at Sriwijaya University were involved. 
The evaluation consists of pretest and posttest, which contain ten questions that are critical thinking oriented - furthermore, achievement data required for determining n-gain value. TABLE 4 reveals the n-gain value.

TABLE 4. The N-Gain

\begin{tabular}{cccc}
\hline Pretest & Postest & N-gain & Criteria \\
\hline 58.6 & 75.2 & 0.38 & Medium \\
\hline
\end{tabular}

Based on Table 4, it is seen that student increase their comprehension in the lesson of electromagnetic induction after implementing the learning activity using the intervented e-learning moodle. The $\mathrm{N}$-gain score is achieved by 0.38 with a medium impact category, according to Cheng (2004). By this result, it is seen that the student improve their understanding regarding the material, and the e-learning empowers the student to develop their skill in answering the question using multi approaches of thinking orientation. Our findings appear to be well supported by Gharib (2016) and Haghparast (2013) that the result confirms the e-learning environment with well-intended strategy might promote critical thinking skills. Moreover, this results concurs well with Nulhakim (2020), and Azhary (2020), and confirm that e-learning might encourage learners' ability regarding 21 st-century skills, and critical thinking is no exception.

\section{CONCLUSION}

In conclusion, the developed e-learning using the moodle platform in the lesson of Electromagnetic Induction is valid for enhancing student's critical thinking and practical for users. Additionally, the instructional integration in learning activity shows improved terms of learner's comprehension regarding the lesson concepts.

Regarding the 21st century framework, teachers should utilize an online platform as the internet has become part of students' daily lives. On the other hand, it is also prominent for educators to involve 21 st-century skills as an intrinsic structure during the learning activity. These skills are crucial for students as they grow up in such an era that requires critical citizenships and competent human resources. The developed product is designed to cultivate necessary thinking skills by embedding CT in a multi-task learning activity. Also, the use of this online media is not limited during the class activity. It means students are capable of conducting self-study regardless of the time and place.

\section{ACKNOWLEDGMENTS}

This study was supported by Universitas Sriwijaya for Hibah Unggulan Kompetitif research Grant No. SP DIPA FKIP 041.01.2.400953/2019 Date 5 December 2018.

\section{REFERENCES}

Archambault, L, Wetzel, K, Foulger, TS \& Williams, MK 2010, 'Professional Development 2.0: Transforming Teacher Education Pedagogy with 21st Century Tools', Journal of Digital Learning in Teacher Education, vol. 27 no. 1, pp. 4-11.

Azhary, HA \& Wiyono, K 2020, 'Pengembangan E-Learning Materi Fluida Dinamis Untuk Mengembangkan Keterampilan Berpikir Kreatif Siswa Sekolah Menengah Atas', Jurnal Pendidikan Fisika Dan Teknologi, vol. 6 no. 1, pp. 1-10.

Bakri, F, Sunaryo, S, Finka, V \& Muliyati, D 2018, 'E-Learning Model for Problem Based Learning on Heat and Thermodynamic Topics in High School', Jurnal Penelitian Dan Pengembangan Pendidikan Fisika, vol. 4 no. 2, pp. 101-112.

Benta, D, Bologa, G \& Dzitac, I 2014, 'E-learning platforms in higher education. Case study', Procedia Computer Science, vol. 31, pp. 1170-176. 
Chandra, RR \& Mahmud, MM 2018, 'Padlet: A Technology Tool for the 21st Century Students Skills Assessment', International Conference on Educational Assessment and Policy, vol. 1, pp. 101-107.

Cheng, KK, Thacker, BA, Cardenas, RL \& Crouch, C 2004, 'Using an online homework system enhances students' learning of physics concepts in an introductory physics course', American journal of physics, vol. 72 no. 11, pp. 1447-453.

Cronje, MO, El-Hussein, M \& Cronje, JJ 2010, 'Defining Mobile Learning in the Higher Education Landscape', Journal of Educational Technology \& Society, vol. 12 no. 3, pp. 12-21.

Dick, W, Carey, L \& Carey, JO 2015, ‘The Systematic Design of Instruction: 8th Edition', Pearson, USA.

Elias, T 2010, 'Universal Instructional Design Principles for Moodle', International Review of Research in Open and Distance Learning, vol. 11, no. 2, pp. 110-24.

Gaeta, ML, Teruel, MP \& Orejudo, S 2012, 'Motivational, Volitional and Metacognitive Aspects of Self Regulated Learning', Electronic Journal of Research in Educational Psychology, vol. 10, no. 26, pp. 73-94.

Gharib, M, Zolfaghari, M, Mojtahedzadeh, R, Mohammadi, A \& Gharib, A 2016, 'Promotion of critical thinking in e-learning: a qualitative study on the experiences of instructors and students', Advances in Medical Education and Practice, vol. 7, pp. 271-79.

Haghparast, M \& Hanum, F 2014, 'Cultivating Critical Thinking Through E-learning Environment and Tools : A Review', Procedia - Social and Behavioral Sciences, vol. 129, pp. 527-35.

Haghparast, M, Hanum, NF \& Abdullah, N 2013, 'Modeling an e-learning tool to cultivate critical thinking in students based on information needs and seeking behavior', Proceedings of 2013 IEEE International Conference on Teaching, Assessment and Learning for Engineering, TALE 2013, August, pp. 521-26.

Hirschel, R 2012, 'Moodle : Students ' perspectives on forums , glossaries and quizzes', Jalt Call, vol. 8, no. 2, pp. 95-112.

Kotzer, S \& Elran, Y 2012, 'Learning and teaching with Moodle-based E-learning environments, combining learning skills and content in the fields of Math and Science \& Technology', 1st Moodle Research Conference, pp. 14-15.

Liaw, S \& Huang, H 2013, 'Computers \& Education Perceived satisfaction, perceived usefulness and interactive learning environments as predictors to self-regulation in e-learning environments', Computers \& Education, vol. 60, no. 1, pp. 14-24.

Malik, A, Novita, Y \& Yeti, A, 2019, 'Enhancing Critical Thinking Skills of Students Related to Temperature and Heat Topics Through Problem Solving Laboratory Model', Jurnal Penelitian Dan Pengembangan Pendidikan Fisika, vol 5, no. 1, pp. 9-20.

Muliyati, D, Marizka, H \& Bakri, F 2019, 'E-Learning Using Wordpress on Physics Materials with The 5E Learning Cycle Strategy', Jurnal Penelitian Dan Pengembangan Pendidikan Fisika, vol 5, no. 2, pp. 101-112.

Newman, G, Wiggins, A, Crall, A, Graham, E, Newman, S \& Crowston, K 2012, 'The future of Citizen science: Emerging technologies and shifting paradigms', Frontiers in Ecology and the Environment, vol. 10, no. 6, pp. 298-304.

Nulhakim, L, Setiawan, FR \& Saefullah, A 2020, 'Improving Students' Creative Thinking Skills Using Problem-Based Learning (PBL) Models Assisted by Interactive Multimedia', Jurnal Penelitian Dan Pengembangan Pendidikan Fisika, vol. 6, no. 1, pp. 9-16.

Peña-ayala, A 2015, 'Intelligent Systems Reference Library 76 Metacognition: Fundaments, Applications, and Trends: A Profile of the Current State-Of-The-Art [1st ed.]', Springer International Publishing, Mexico. 
Psycharis, S, Chalatzoglidis, G \& Kalogiannakis, M 2013, 'Moodle as a Learning Environment in Promoting Conceptual Understanding for Secondary School Students', Eurasia Journal of Mathematics, Science and Technology Education, vol. 9, no. 1, pp. 11-21.

Rieckmann, M 2012, 'Future-oriented higher education : Which key competencies should be fostered through university teaching and learning ?', Futures, vol. 44, no. 2, pp. 127-135.

Sadeghi, B, Hassani, MT \& Rahmatkhah, M 2014, 'The Relationship between EFL Learners"e Metacognitive Strategies, and Their Critical Thinking Bahador', Journal of Language Teaching and Research, vol. 5, no. 5, pp. 1167-1175.

Sugiyono, S 2015, 'Metode Penelitian Kuantitatif, Kualitatif, dan R\&D', Bandung. Alfabeta.

Susilawati, S, Nurfina, N \& Paidi, A 2020, 'Instructional Design on The Environmental Pollution Theme in the Higher Education', Earth and Environmental Science, vol. 485, pp. 1-6. 
